\title{
TRACER STUDY ALUMNI DALAM MENINGKATKAN MUTU AKADEMIK DI FAKULTAS TARBIYAH DAN ILMU KEGURUAN IAIN DANGSIDIMPUAN
}

\author{
ZULHIMMA \\ Lecturer of Tarbiyah and Paedagogy Faculty in State College for Islamics Studies \\ Padangsidimpuan. \\ E-mail: zulhimma_yes@yahoo.com
}

\begin{abstract}
Tracer Study is an effective media that is used to track the whereabouts and condition of alumni. Tracer study has a very important role in filtering the information of the alumni as an evaluation and development of the college towards a better. Alumni brings its own benefits for universities, either in academic and pragmatic fields, such as: updating of based curriculum relevant to the needs of the market / the world of work, utilization of alumni as guest lecturers, professional lecturers, seminars, training, etc.
\end{abstract}

Keys Words: Tracer, study, alumni, quality, academic.

\begin{abstract}
Abstrak
Tracer Study merupakan media efektif yang digunakan untuk melacak jejak keberadaan dan kondisi alumni. Tracer study memiliki peran yang sangat penting dalam menjaring informasi dari alumni sebagai bahan evaluasi dan pengembangan perguruan tinggi ke arah yang lebih baik. Alumni membawa manfaat tersendiri bagi perguruan tinggi, baik dalam akademik maupun bidang pragmatis, seperti: pemutakhiran kurikulum berbasis relevansi dengan kebutuhan pasar / dunia kerja, pemanfaatan alumni sebagai dosen tamu, dosen profesional, seminar, training dan lain-lain.
\end{abstract}

Kata Kunci: Tracer, study, alumni, mutu, akademik

\section{PENDAHULUAN}

\section{Latar Belakang Masalah}

Perguruan tinggi merupakan bagian dari masyarakat yang mempunyai tugas dan kewajiban mempersiapkan sumber daya manusia yang berkualitas dan mampu membangun bangsa dalam menghadapi era tantangan global. Keberadaan, kemajuan, dan keberlanjutan sebuah perguruan tinggi tidak dapat dilepaskan dari dukungan alumni atau lulusannya dan berbagai stakeholders sebagai pengguna lulusan.

Alumni merupakan unsur yang tidak dapat dipisahkan dari perguruan Tinggi, karena alumni adalah representatif dari perguruan tinggi. Alumni juga membawa 
manfaat tersendiri bagi perguruan tinggi, baik dalam akademik maupun bidang pragmatis, seperti : pemutakhiran kurikulum berbasis relevansi dengan kebutuhan pasar / dunia kerja, pemanfaatan alumni sebagai dosen tamu, dosen profesional, seminar, training dan lain-lain.

Perguruan tinggi harus mampu menjalin hubungan yang erat dan harmonis dengan alumninya sebagai jembatan penghubung dengan pengguna lulusan. Hubungan tersebut hanya dapat dijalin dengan baik apabila terdapat media yang tepat yang dapat digunakan untuk komunikasi dua arah antara perguruan tinggi (almamater) dan lulusan (alumni).

Tracer Study merupakan media efektif yang digunakan untuk melacak jejak keberadaan dan kondisi alumni. Tracer study memiliki peran yang sangat penting dalam menjaring informasi dari alumni sebagai bahan evaluasi dan pengembangan perguruan tinggi ke arah yang lebih baik. "Para Pelaku proses pendidikan tinggi di perguruan tinggi, baik yang memimpin maupun yang dipimpin, harus memiliki komitmen yang tinggi untuk senantiasa menjamin dan meningkatkan mutu pendidikan tinggi yang diselenggarakannya". ${ }^{1}$

Fakultas Tarbiyah dan Ilmu Keguruan sebagai salah satu Fakultas di IAIN Padangsidimpuan merupakan salah satu Lembaga Pendidikan Tenaga Kependidikan yang bertugas mencetak guru. Dalam Peraturan Pemerintah Republik Indonesia No. 74 Tahun 2008 tentang guru telah menggariskan bahwa hal ini menjadi kewenangan lembaga pendidikan tenaga kependidikan, yang disebut sebagai penyediaan guru berbasis perguruan tinggi. ${ }^{2}$

Kontribusi IAIN Padangsidimpuan telah dirasakan secara nyata dalam kehidupan masyarakat Kota Padangsidimpuan dan kabupaten sekitarnya, bahkan kota dan kabupaten lain di Indonesia. Kontribusi itu bukan hanya pada aspek 'keagamaan' tetapi mencakup semua sendi kehidupan.

Alumni IAIN Padangsidimpuan sudah menyebar ke berbagai daerah di sekitar propinsi Sumatera Utara dan Sumatera Barat, berbagai profesi dimasuki oleh alumni IAIN Padangsidimpuan, mulai dari guru, kepala sekolah, pegawai di kanwil kementerian agama, pegawai di pemerintahan daerah, hakim, dan lain-lain. Hampir semua lini kehidupan ditemukan kiprah alumni IAIN Padangsidimpuan.

Fakultas Tarbiyah dan Ilmu Keguruan Institut Agama Islam Negeri (IAIN) Padangsidimpuan merupakan salah satu fakultas yang ada di IAIN Padangsidimpuan telah berperan mencetak guru di Kota Padangsidimpuan dan kota- kota disekitarnya, yaitu guru agama Islam, guru matematika dan guru Bahasa Inggris, melalui jurusan Pendidikan Agama Islam, Tadris Matematika dan Tadris Bahasa Inggris.

\footnotetext{
${ }^{1}$ Kementerian Pendidikan Nasional. Sistem Penjaminan Mutu Perguruan Tingg , (Jakarta: Direktorat Jenderal Pendidikan Tinggi, 2010), hlm. 23

${ }^{2}$ Sudarwan Danim. Pengembangan Profesi Guru, ( Jakarta: Kencana Prenada Grup, 2012), hlm. 3
} 
Fakultas Tarbiyah dan Ilmu Keguruan IAIN Padangsidimpuan telah banyak melahirkan alumni - alumninya, yaitu Jurusan Pendidikan Agama Islam sebanyak 2980 guru, Jurusan Matematika sebanyak 205 dan Jurusan Bahasa Inggris sebanyak 185 guru. Guru - guru ini tersebar di semua sekolah yang ada di Kota Padangsidimpuan dan kabupaten sekitarnya. Guru - Guru ini telah dibekali dengan berbagai ilmu keislaman dan kependidikan agar mereka menjadi guru yang profesional, mempunya kompetensi yang diharapkan untuk dapat mendidik anak bangsa.

Fakultas Tarbiyah dan Ilmu Keguruan berkomitmen untuk memperbaiki kualitas pembelajaran secara terus menerus melalui perbaikan kurikulum, peningkatan kualitas pengajar, serta penyesuaian dan peningkatan sistem pembelajaran dengan berbekal berbagai informasi yang diperoleh dari alumni melalui tracer study sehingga dapat mengatasi kesenjangan antara lulusan dan kebutuhan pengguna lulusan. Tracer Study merupakan media efektif yang digunakan untuk melacak jejak keberadaan dan kondisi alumni. Tracer study memiliki peran yang sangat penting dalam menjaring informasi dari alumni sebagai bahan evaluasi dan pengembangan mutu akademik perguruan tinggi.

Dengan banyaknya alumni Fakultas Tarbiyah dan Ilmu Keguruan yang yang sudah di lahirkan maka penulis tertarik untuk melakukan penelusuran alumni dalam rangka memperoleh masukan untuk perbaikan dan peningkatan mutu pembelajaran di Fakultas Tarbiyah dan Ilmu Keguruan

\section{Identifikasi dan Batasan Masalah}

Berdasarkan latar belakang masalah di atas, dapat diidentifikasi berbagai permasalahan terkait dengan lulusan yang sudah dihasilkan oleh Fakultas Tarbiyah dan Ilmu Keguruan. Permasalahnya adalah:

a. Kurangnya informasi tentang kinerja lulusan Fakultas Tarbiyah dan Ilmu Keguruan sejak menghasilkan lulusan

b. Belum diperolehnya data tentang penyebaran lulusan Fakultas Tarbiyah dan Ilmu Keguruan

c. Belum diperolehnya data tentang jenis - jenis pekerjaan yang diperoleh lulusan Fakultas Tarbiyah dan Ilmu Keguruan.

d. Belum diperolehnya informasi tentang kendala yang dihadapi lulusan dalam memperoleh pekerjaan.

e. Belum diperolehnya informasi tentang kendala yang dihadapi lulusan dalam mengembangkan diri.

Dari Identifikasi masalah di atas, tidak mungkin semuanya terpecahkan melalui satu kali penelitian. Oleh karena itu dalam penelitian ini masalahnya dibatasi pada persoalan kondisi alumni Fakultas Tarbiyah dan Ilmu Keguruan selama menjalani 
perkuliahan dan sesudah menyelesaikan perkuliahan dan kendala - kendala yang dihadapi selama perkuliahan dan tanggapan pengguna terhadap kinerja alumni.

\section{Batasan Istilah}

Agar tidak terjadi kekeliruan dalam memahami penelitian ini, maka batasan istilah adalah sebagai berikut:

a. Tracer Study adalah: studi mengenai lulusan lembaga penyelenggara pendidikan tinggi. Istilah lain yang sering digunakan adalah "Graduate survey", "Alumni Researches ", dan Follow-up Study ${ }^{3}$. Maka Tracer Study yang dimaksud dalam peneltian ini adalah usaha menelusuri alumni Fakultas Tarbiyah dan Ilmu Keguruan untuk memperoleh umpan balik dalam menyempurnakan kurikulum dan proses pembelajaran.

b. Alumni adalah orang - orang yang telah mengikuti atau tamat dari suatu sekolah atau perguruan tinggi. ${ }^{4}$ Alumni yang dimaksud dalam penelitian ini adalah lulusan dari IAIN Padangsidimpuan Fakultas Tarbiyah dan Ilmu Keguruan Jurusan Pendidikan Agama Islam, Tadris Matematika dan Tadris Bahasa Inggris.

c. Mutu adalah baik buruk sesuatu kualitas. ${ }^{5}$ Mutu yang dimaksud dalam penelitian ini adalah peningkatan kualitas pembelajaran di Fakultas Tarbiyah dan Ilmu Keguruan IAIN Padangsidimpuan

d. Akademik adalah perguruan tinggi yang mengajarkan sesuatu pengetahuan keahlian. ${ }^{6}$

Dari pengertian - pengertian di atas dapat diambil kesimpulan bahwa yang dimaksud dengan Tracer study alumni dalam meningkatkan mutu pembelajaran adalah Studi tentang Penelusuran Alumni Fakultas Tarbiyah dan Ilmu Keguruan Jurusan Pendidikan Agama Islam, Tadris Matematika dan Tadris Bahasa Inggris untuk mendapatkan umpan balik bagi perbaikan pembelajaran di IAIN Padangsidimpuan.

\section{Rumusan Masalah}

Dari latar belakang diatas, maka dapat dirumuskan masalah sebagai berikut:

a. Bagaimanakah kondisi lulusan selama mengikuti proses pembelajaran di Fakultas Tarbiyah dan Ilmu Keguruan IAIN Padangsidimpuan?

b. Bagaimanakah kondisi lulusan setelah mengikuti proses pembelajaran di Fakultas Tarbiyah dan Ilmu Keguruan IAIN Padangsidimpuan?

c. Bagaimana Penilaian pengguna terhadap kinerja lulusan Fakultas Tarbiyah dan Ilmu Keguruan IAIN Padangsidimpuan?

\section{KAJIAN TEORI}

${ }^{3}$ Kementerian Pendidikan dan Kebudayaan . Buku Panduan Sistem Pusat Karir, ( Jakarta: Dirjen Pendidikan Tinggi Direktorat Pembelajaran dan Kemahasiswaan), hlm.25

${ }^{4}$ Desy Anwar. Kamus Lengkap Bahasa Indonesia, ( Surabaya: Karya Abdi Tama, 2001, hlm.33

${ }^{5}$ Ibid. hlm. 286

${ }^{6}$ Ibid., hlm. 22 


\section{Tracer Study}

Tracer Study atau yang disebut sebagai survey alumni adalah studi mengenai lulusan lembaga penyelenggara pendidikan tinggi. Studi ini mampu menyediakan berbagai informasi yang bermanfaat bagi kepentingan evaluasi hasil pendidikan tinggi dan selanjutnya dapat digunakan untuk penyempurnaan dan penjaminan kualitas lembaga pendidikan tinggi dan dunia kerja profesional, menilai relevansi pendidikan tinggi, informasi bagi pemangku kepentingan ( stakeholders) dan kelengkapan persyaratan bagi akreditasi pendidikan tinggi .

Tracer study bertujuan untuk :

a). Menggali informasi apakah terdapat kesenjangan antara pendidikan yang diberikan dengan dunia kerja (dunia bisnis) yang dimasuki oleh alumni.

b). Menggali informasi lebih rinci mengenai relevansi kompetensi antara kebutuhan pengguna lulusan dengan yang diperoleh alumni.

c). Menggali informasi mengenai perkembangan dunia kerja untuk masa yang akan datang sebagai langkah antisipasi penyesuaian bagi perguruan tinggi

Ditengah massifikasi pendidikan tinggi di Indonesia yang ditandai oleh menjamurnya pembukaan institusi - institusi baru pendidikan tinggi, perhatian terhadap keterkaitan antara visi, misi dan tujuan pendidikan tinggi dengan perubahan - perubahan besar di dunia kerja perlu mendapat tekanan khusus dan berkesinambungan. Disisi lain kompetensi lulusan Perguruan Tinggi juga mengalami pergeseran, yaitu makin disadari pentingnya kompetensi yang bersifat generik dan manajerial di samping yang bersifat spesifik dan tehnis. ${ }^{7}$

Pada saat sekarang ini para alumni dihadapkan pada persaingan dunia kerja, pihak perguruan tinggi perlu merancang sistem pendidikan yang sesuai dengan perubahan tuntutan lingkungan eksternal dan juga kebutuhan dunia pendidikan. Untuk itu, perguruan tinggi perlu secara rutin mengikuti perkembangan dan perubahan kebutuhan dunia praktis, agar terjalin link and match ,kesesuaian dan kesepadan antara dunia pendidikan dengan dunia kerja

Untuk dapat melihat mutu alumni perlu penilaian kinerja. Konsep penilaian kinerja ditujukan untuk meningkatkan aspek - aspek kinerja yang meliputi: (1) sasaran yang dicapai, (2) Kompetensi yang meliputi pengetahuan, ketrampilan, sikap dan (3) efektivitas kerja ${ }^{8}$.

Evaluasi Kinerja lulusan dari Pihak Pengguna Lulusan sangat diperlukan untuk dapat digunakan sebagai umpan balik terhadap proses pendidikan di perguruan tinggi. Badan Akreditasi Nasional Perguruan Tinggi (BAN PT) menggariskan evaluasi kinerja alumni yang akan dilihat adalah integritas (etika dan moral), keahlian

\footnotetext{
${ }^{7}$ Kementerian Pendidikan dan Kebudayaan, Buku Panduan Sistem ......, hlm. 25

${ }^{8}$ Surya Dharma. Manajemen Kinerja, ( Yogyakarta: Pustaka Pelajar, 2012), hlm. 2
} 
berdasarkan bidang ilmu (profesionalisme), Bahasa Inggris, penggunaan teknologi informasi, komunikasi, kerjasama tim dan pengembangan diri. ${ }^{9}$

\section{Mutu Akademik}

Dalam penyelenggaraan perguruan tinggi, jaminan mutu akademik sangat diperlukan. Perguruan tinggi harus mampu terus menerus menyesuaikan diri dengan perkembangan ilmu dan teknologi serta realitas sosial budaya yang terus berkembang.

Mutu akademik merupakan upaya pencapaian tujuan pendidikan dan kompetensi lulusan serta hasil - hasil penelitian dan layanan masyarakat yang telah ditetapkan sesuai rencana strategis dan standar akademik. Dalam hal ini menyangkut aspek masukan, proses dan keluaran serta nilai dan derajat kebaikan, keutamaan, kebenaran dan kesempurnaan. ${ }^{10}$

Dalam melaksanakan kegiatan akademik, kurikulum memegang peranan penting.

Kurikulum merupakan aktivitas yang harus dilakukan oleh mahasiswa dan dosen dalam rangka mencapai suatu tujuan, termasuk di dalamnya kegiatan belajar mengajar, mengatur strategi dalam proses belajar mengajar, mengevaluasi program pengembangan, pengajaran dan sebagainya. "Sebagai suatu rencana pengajaran, kurikulum berisi tujuan yang ingin dicapai, bahan yang akan disajikan, kegiatan pengajaran, alat-alat pengajaran dan jadwal waktu pengajaran."11

Dalam suatu proses pembelajaran, terdapat berbagai komponen yang satu sama lainnya saling berinteraksi dan berinterelasi. Komponen -komponen tersebut adalah dosen, mahasiswa, tujuan pembelajaran, materi pemebelajaran, metode atau strategi pembelajaran.Komponen - komponen pembelajaran perlu dikelola dengan baik agar menghasilkan mutu akademik yang baik pula.

Dosen sebagai salah satu komponen dalam kegiatan pembelajaran, memiliki posisi yang sangat menentukan keberhasilan pendidikan, karena fungsi utama dosen adalah merancang, mengelola, melaksanakan dan mengevaluasi perkuliahan. Salah satu faktor yang mempengaruhi Dosen adalah kinerjanya didalam merencanakan / merancang, melaksanakan dan mengevaluasi proses pembelajaran.

Dalam Undang - Undang Republik Indonesia No. 14 tahun 2005 tentang Guru dan Dosen pada pasal 1 disebutkan bahwa dosen adalah pendidik profesional dan ilmuwan dengan tugas utama mentransformasikan, mengembangkan, dan

\footnotetext{
${ }^{9}$ Badan Akreditasi Perguruan Tinggi, Buku III A Borang Akreditasi Program Studi, (Jakarta: BAN PT, 2008),hlm.6

${ }^{10}$ Sekolah Tinggi Agama Islam Negeri Padangsidimpuan., Manajemen Mutu Akademik ( Padangsidimpuan: STAIN Psp, 2012), hlm. 6 2008), hlm.7

${ }^{11}$ Nana Syaodih Sukmadinata. Pengembangan kurikulum, teori dan praktek, (Bandung: Remaja Rosda Karya,
} 
menyebarluaskan ilmu pengetahuan, tehnologi, dan seni melalui pendidikan, penelitian, dan pembinaan kepada masyarakat. ${ }^{12}$

Dosen bermutu adalah dambaan bagi mahasiswanya. Banyak cara yang dilakukan oleh perseorangan dosen atau lembaga untuk meningkatkan mutu dosen, seperti melalui peningkatan akademis, workshop, penataran, pelatihan, peningkatan kinerja, studi banding dan sebagainya.

Lebih jauh Undang - Undang Guru dan Dosen menambahkan bahwa Dosen dalam melaksanakan tugas keprofesionalannya, wajib untuk:

a. Melaksanakan pendidikan, penelitian, dan pengabdian kepada masyarakat.

b. Merencanakan, melaksanakan proses pembelajaran, serta menilai dan mengevaluasi hasil pembelajaran

c.Meningkatkan dan mengembangkan kualifikasi akademik dan kompetensi secara berkelanjutan sejalan dengan perkembangan ilmu pengetahuan, tehnologi dan seni.

d. Bertindak objektif dan tidak diskriminatif atas dasar pertimbangan jenis kelamin, agama, suku, ras, kondisi fisik tertentu, atau latar belakang sosio-ekonomi peserta didik dalam pembelajaran.

e. Menjunjung tinggi peraturan perundang - undangan, hukum, dan kode etik, serta nilai-nilai agama dan etika.

f. Memelihara dan memupuk persatuan dan kesatuan bangsa. ${ }^{13}$

Dalam kegiatan akademik, keberadaan mahasiswa juga menentukan mutu suatu lemabaga pendidikan. Mahasiswa merupakan anggota civitas akademika di perguruan tinggi. Dalam Undang - Undang Republik Indonesia Nomor 12 Tahun 2012 tentang pendidikan tinggi dalam pasal 13 ayat 1 disebutkan bahwa mahasiswa sebagai anggota civitas akademika diposisikan sebagai insan dewasa yang memiliki kesadaran sendiri dalam mengembangkan potensi diri di perguruan tinggi untuk menjadi intelektual, ilmuan, praktisi, dan/ atau profesional. ${ }^{14}$

Mahasiswa mempunyai harapan besar untuk menjadi seorang sarjana ketika mereka telah menyelesaikan studinya di tingkat perguruan tinggi.

\section{Fakultas Tarbiyah dan Ilmu Keguruan IAIN Padangsidimpuan}

Institut Agama Islam Negeri (IAIN) Padangsidimpuan berawal dari Fakultas Tarbiyah Universitas Nahdatul Ulama Sumatera Utara (UNUSU) Padangsidimpuan yang didirikan berkat perjuangan ulama dan umara di Padangsidimpuan dan

${ }^{12}$ Sekolah Tinggi Agama Islam Negeri Padangsidimpuan. Standar Dosen , ( Padangsidimpuan: STAIN Psp, 2013),

${ }^{13}$ Kementerian Pendidikan Nasional. Sistem Penjaminan Mutu Perguruan Tinggi, Op.Cit., hlm.88.

${ }^{14}$ Sekolah Tinggi Agama Islam Negeri Padangsidimpuan. Standar Mutu Mahasiswa , ( Padangsidimpuan: STAIN Psp, 2013), hlm.5 
Tapanuli Selatan 1963. Pada waktu itu, UNUSU Padangsidimpuan mengasuh tiga fakultas, yaitu: Syariah, Tarbiyah dan Ushuluddin.

Sampai saatnya mereka bersepakat untuk menyerahkan pengelolaan salah satu fakultasnya yakni Fakultas Tarbiyah dinegerikan menjadi Fakultas Tarbiyah Imam Bonjol Padang Sumatera Barat, cabang Padangsidimpuan. Saat itu bertepatan dengan 1 Juni 1968. Sejak itu, tanggal ini dijadikan sebagai hari kelahiran STAIN Padangsidimpuan. Pada 1973, sejalan dengan berdirinya IAIN Sumatera Utara Medan yang berada di Propinsi Sumatera Utara, maka Fakultas Tarbiyah yang berada di propinsi yang sama ini dipindahkan pengasuhannya ke IAIN Sumatera Utara Medan.

Dalam perkembangannya, Sistem Pendidikan Nasional dan kebijakan Mendiknas tahun 1997 melarang adanya fakultas cabang dan dua fakultas yang sama pada satu institut atau universitas. Karenanya, fakultas Tarbiyah IAIN Sumatera Utara Padangsidimpuan berubah menjadi STAIN Padangsidimpuan.

Seiring dengan pengembangan lembaga dan berkat usaha kerja keras pimpinan STAIN Padangsidimpuan, maka berdasarkan Peraturan Presiden Republik Indonesia Nomor 52 Tahun 2013 tentang Perubahan Sekolah Tinggi Agama Islam Negeri Padangsidimpuan Menjadi Institut Agama Islam Negeri Padangsidimpuan maka STAIN Padangsidimpuan menjadi IAIN Padangsidimpuan. Dan berdasarkan Peraturan Menteri Agama Republik Indonesia Nomor 93 Tahun 2013 tentang Organisasi dan Tata Kerja Institut Agama Islam Negeri Padangsidimpuan, IAIN Padangsidimpuan mempunyai 4 Fakultas, yaitu Fakultas Tarbiyah dan Ilmu Keguruan, Fakultas Syariah dan Hukum Islam, Fakultas Dakwah dan Ilmu Komunikasi dan Fakultas Ekonomi dan Bisnis Islam, yang masing-masing mengasuh Jurusan, yaitu Jurusan Pendidikan Agama Islam (PAI), Pendidikan Bahasa Arab ,Jurusan Tadris Matematika dan Jurusan Tadris Bahasa Inggris di Fakultas Tarbiyah dan Ilmu Keguruan; Ahwal asy-Syakhsiyah, Hukum Ekonomi Syariah, Hukum Tata Negara, Perbandingan Mazhab dan Alqur'an Tafsir di Fakultas Syariah dan Hukum Islam , Jurusan Perbankan Syariah dan Ekonomi Syariah ( ES) di Fakultas Ekonomi dan Bisnis Islam; Jurusan Komunikasi Penyiaran Islam , Bimbingan Konseling Islam ( BKI), Manajemen Dakwah dan Pengembangan Masyarakat Islam di Fakultas Dakwah dan Ilmu Komunikasi.

Dari 4 Fakultas yang ada di IAIN Padangsidimpuan, yang paling tua adalah Fakultas Tarbiyah dan Ilmu Keguruan. Fakultas Tarbiyah dan Ilmu Keguruan membina 4 jurusan yaitu jurusan Pendidikan Agama Islam, Tadris Matematika, Tadris Bahasa Inggris dan Pendidikan Bahasa Arab.

\section{METODOLOGI PENELITIAN}

\section{Tempat dan Waktu Penelitian}


Penelitian ini dilakukan pada Alumni Fakultas Tarbiyah dan Ilmu Keguruan IAIN Padangsidimpuan. Para alumni tersebut tersebar di berbagai kota dan kabupaten di propinsi Sumatera Utara, kota Padangsidimpuan, Kabupaten Tapanuli Selatan, Kab. Tapanuli Tengah, Tapanuli Utara, Sibolga, Kab.Palas, Kab. Paluta, Penelitian ini akan dilaksanakan dalam waktu 6 bulan dimulai dari bulan Mei sampai pembuatan laporan penelitian bulan Oktober 2014.

\section{JenisPenelitian}

Kajian tracer study ini merupakan penelitian deskriptif evaluatif yang berusaha mendeskripsikan profil lulusan dan relevansi materi kuliah kurikulum Jurusan PAI, TMM dan TBI melalui pendekatan survey. Tracer study dilakukan secara sensus terhadap lulusan program S1 Fakultas Tarbiyah dan Ilmu Keguruan . Dalam penelitian ini, penulis akan menggunakan penelitian kualitatif untuk mendapatkan deskripsi tentang data pendahuluan, karakteristik sosio-biografi, pengalaman akademik dan non akademik, Pencarian kerja dan transisi ke dunia kerja dan Pekerjaan dan kompetensi .

\section{Sumber Data}

Informan yang akan dijadikan sumber data primer dalam penelitian ini adalah alumni Fakultas Tarbiyah dan Ilmu Keguruan jurusan Pendidikan Agama Islam, Tadris Matematika dan Tadris Bahasa Inggris, yang telah menyelesaikan studinya di IAIN Padangsidimpuan.

\section{InstrumenPengumpulan Data}

Adapun instrument yang dijadikan dalam pengumpulan data dalam penelitian ini adalah sebagai berikut: wawancara dan angket.

\section{Analisa Data}

Penelitian evaluasi ini bersifat deskriptif, dengan pendekatan kualitatif. Semua data dikumpulkan melalui angket maupun dokumentasi dianalisis dengan menggunakan tehnik analisis deskriptif persentase. Data yang berhasil dikumpulkan kemudian dideskripsikan selanjutnya diambil kesimpulan tentang masing - masing komponen atas dasar kriteria yang telah ditentukan.

\section{HASIL PENELITIAN}

1. Kondisi Alumni selama mengikuti proses pembelajaran di Fakultas Tarbiyah dan Ilmu Keguruan IAIN Padangsidimpuan

Dalam kaitannya dengan Proses pembelajaran yang dilaksanakan dosen, aspek yang diteliti adalah Pola penjadwalan perkuliahan, Ketepatan dosen mengajar sesuai dengan jadwal perkuliahan, Dosen memenuhi standart jumlah pertemuan, Penilaian dosen terhadap hasil akhir belajar mahasiswa, Dosen menunjukkan kualifaid dalam 
bidangnya dan Dosen memberikan pelayanan di luar jadwal. Alumni yang baru menyelesaikan perkuliahan mengisi angket tentang ini dilaksanakan dosen di Fakultas Tarbiyah dan Ilmu Keguruan, diperoleh data sebagai berikut:

Tabel 1. Perkuliahan oleh Dosen

\begin{tabular}{|l|l|c|c|c|}
\hline NO & Pernyataan & $\begin{array}{c}\text { Memuaska } \\
\mathrm{n}\end{array}$ & Baik & Sedang \\
\hline 1 & Pola penjadwalan perkuliahan & $85 \%$ & $10 \%$ & $5 \%$ \\
\hline 2 & $\begin{array}{l}\text { Ketepatan dosen mengajar sesuai dengan } \\
\text { jadwal perkuliahan }\end{array}$ & $87 \%$ & $90 \%$ & $4 \%$ \\
\hline 3 & $\begin{array}{l}\text { Dosen memenuhi standart jumlah } \\
\text { pertemuan }\end{array}$ & $95 \%$ & $5 \%$ & $5 \%$ \\
\hline 4 & $\begin{array}{l}\text { Penilaian dosen terhadap hasil akhir } \\
\text { belajar mahasiswa }\end{array}$ & $90 \%$ & $5 \%$ \\
\hline 5 & $\begin{array}{l}\text { Dosen menunjukkan kualifaid dalam } \\
\text { bidangnya }\end{array}$ & $96 \%$ & $15 \%$ & $5 \%$ \\
\hline 6 & $\begin{array}{l}\text { Dosen memberikan pelayanan diluar } \\
\text { jadwal }\end{array}$ & $80 \%$ & $5 \%$ \\
\hline
\end{tabular}

Dari tabel diatas dapat digambarkan dalam grafik:
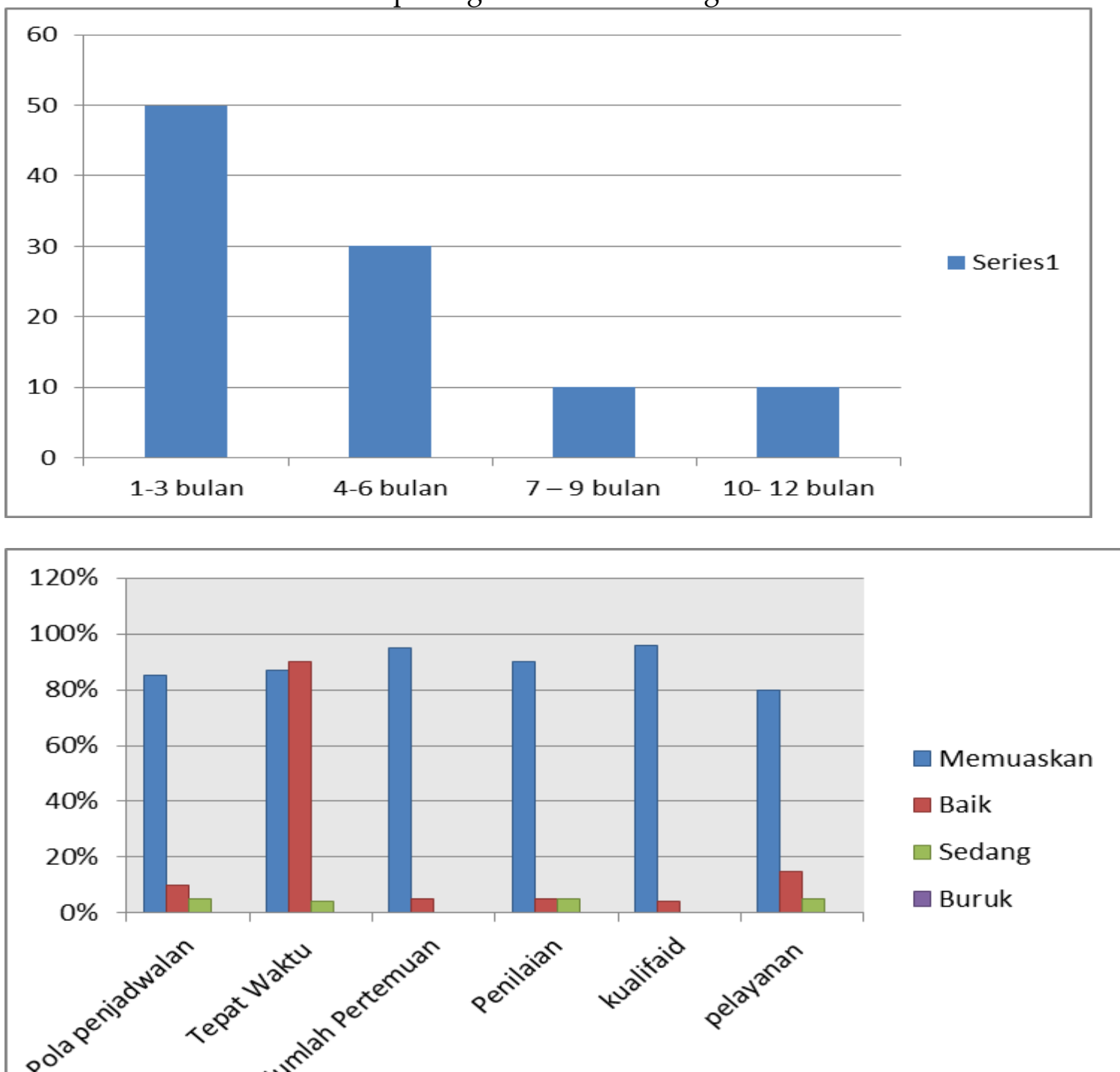
Dari data di atas dapat kita pahami bahwa alumni memandang bahwa jadwal perkuliahan dilaksanakan dengan baik $(85 \%)$, dosen mengajar sesuai dengan jadwal perkuliahan $(87 \%)$, jumlah pertemuan di dalam proses perkuliahan memenuhi standar (95\%), penilaian yang dilaksanakan dosen memuaskan bagi mahasiswa (90\%) , Dosen menunjukkan kualifaid dalam bidangnya (96\%) dan Dosen memberikan pelayanan diluar jadwal ( $80 \%$ ).

2. Kondisi Alumni setelah menyelesaikan perkuliahan di Fakultas Tarbiyah dan Ilmu Keguruan IAIN Padangsidimpuan

a. Waktu tunggu memperoleh pekerjaan pertama

Dari 100 orang alumni yang dijadikan sampel diperoleh bahwa:

Tabel 2.Waktu Tunggu Memperoleh Pekerjaan Pertama

\begin{tabular}{|l|l|l|}
\hline Masa Tunggu & Banyaknya & Persentase \\
\hline $1-3$ bulan & 50 & $50 \%$ \\
\hline $4-6$ bulan & 30 & $30 \%$ \\
\hline $7-9$ bulan & 10 & $15 \%$ \\
\hline $10-12$ bulan & 10 & $5 \%$ \\
\hline & 100 & 100 \\
\hline
\end{tabular}

Adapun Grafik dari data tersebut di atas dapat dilihat dari gambar berikut ini:

a. Pekerjaan Pertama setelah lulus dari Fakultas Tarbiyah dan Ilmu Keguruan IAIN Padangsidimpuan

Setelah menyelesaikan kuliahnya alumni Fakultas Tarbiyah dan Ilmu Keguruan memperoleh pekerjaan pertama sebagaimana tercantum dalam tabel berikut di bawah ini:

Tabel 3. Pekerjaan pertama

\begin{tabular}{|l|l|l|}
\hline Pekerjaan & Banyaknya & Persentase \\
\hline Pengelola Lembaga Pendidikan & 3 & $5 \%$ \\
\hline Dosen & 5 & $5 \%$ \\
\hline Konselor & - & - \\
\hline Guru & 85 & $85 \%$ \\
\hline Tutor & 1 & $1 \%$ \\
\hline Peneliti & - & - \\
\hline Tehnisi di Bidang Pendidikan & 4 & $4 \%$ \\
\hline Lainnya & 2 & $2 \%$ \\
\hline
\end{tabular}

Adapun Grafik dari data tersebut di atas dapat dilihat dari gambar berikut ini: 


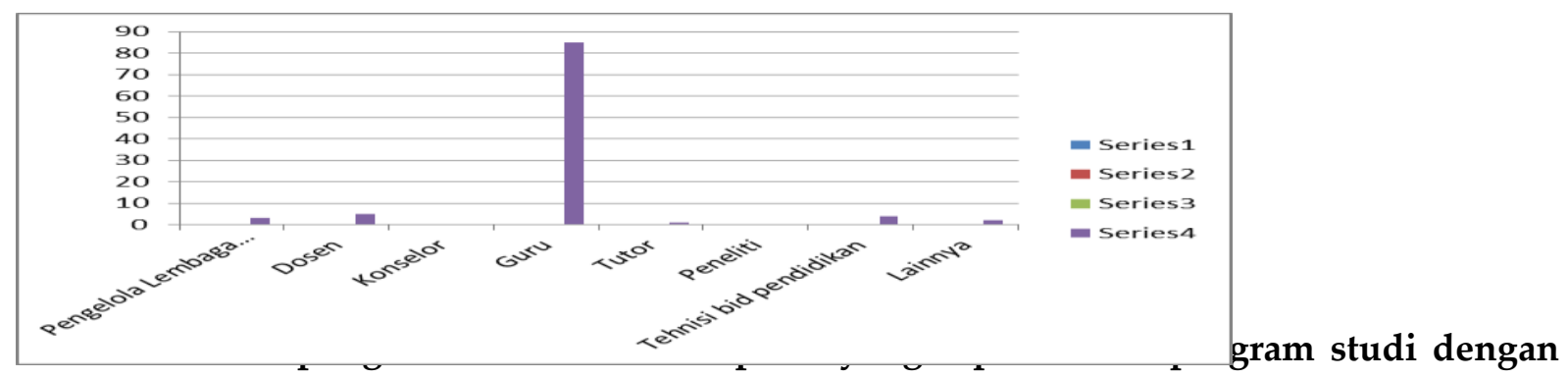

tuntutan pekerjaan

Pengetahuan dan ketrampilan yang diperoleh di program studi akan mendukung terhadap pelaksanaan pelaksanaan pekerjaan yang dilakukan oleh alumni. Dari hasil penelitian diperoleh data sebagaimana dalam Tabel di bawah ini:

Tabel 4. Kesesuaian pengetahuan dan ketrampilan dengan tuntutan pekerjaan

\begin{tabular}{|l|l|l|}
\hline $\begin{array}{l}\text { Tingkat } \\
\text { Kesesuaian }\end{array}$ & Banyaknya & Persentase \\
\hline$\geq 86 \%$ & 92 & $92 \%$ \\
\hline $76 \%-85 \%$ & 4 & $4 \%$ \\
\hline $61 \%-75 \%$ & 2 & $2 \%$ \\
\hline $51 \%-59 \%$ & 1 & $1 \%$ \\
\hline$\leq 50 \%$ & 1 & $1 \%$ \\
\hline & 100 & 100 \\
\hline
\end{tabular}

Adapun Grafik dari data tersebut di atas dapat dilihat dari gambar berikut ini:

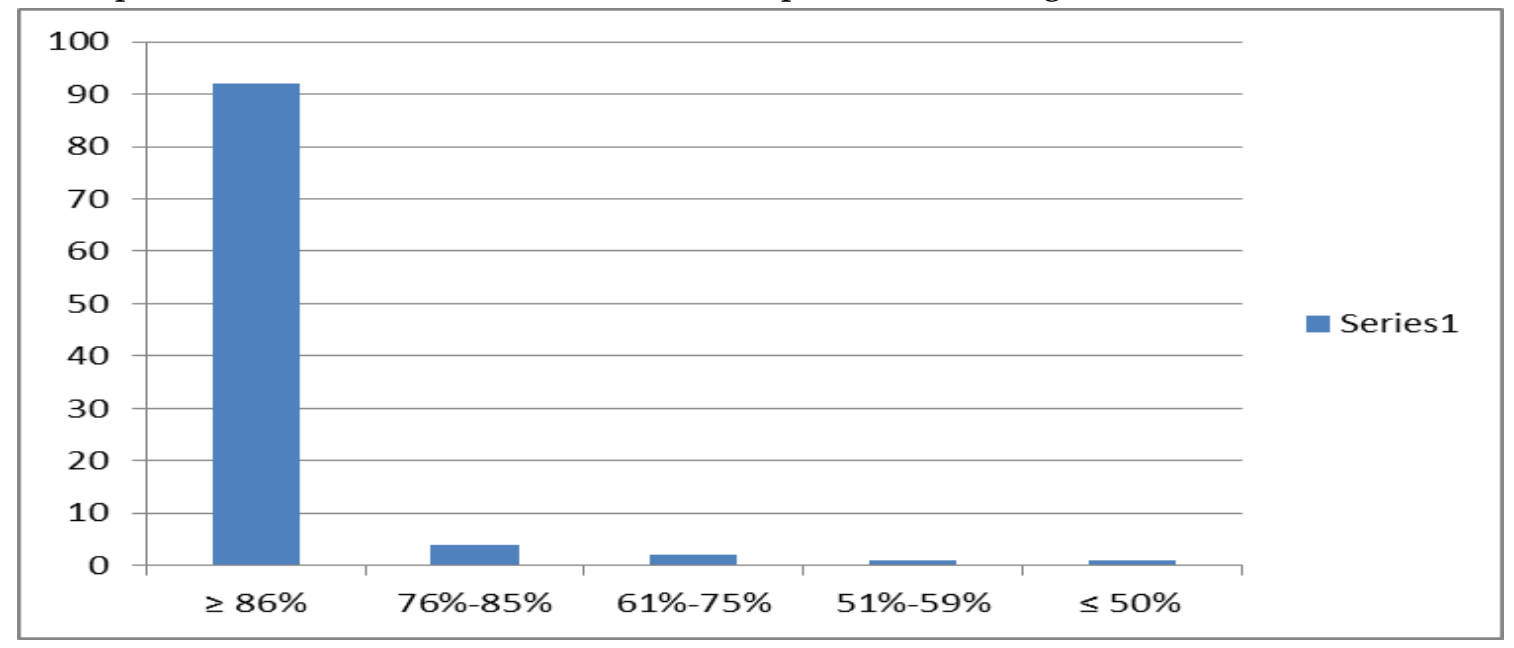

\section{d. Informasi tentang pekerjaan pertama kali}

Informasi tentang pekerjaan sangat dibutuhkan oleh alumni yang telah menyelesaikan perkuliahannya. Alumni Fakultas Tarbiyah dan Ilmu Keguruan memperoleh Informasi tentang pekerjaan sebagaimana dalam tabel berikut:

Tabel 5. Sumber Informasi tentang pekerjaan

\begin{tabular}{|l|l|l|}
\hline Sumber Informasi & Banyaknya & Persentase \\
\hline
\end{tabular}




\begin{tabular}{|l|l|l|}
\hline Program Studi/Fakultas & 20 & $20 \%$ \\
\hline Dosen & 10 & $10 \%$ \\
\hline Organisasi Alumni & 27 & $27 \%$ \\
\hline Media Cetak & 3 & $3 \%$ \\
\hline Media Elektronik & 10 & $10 \%$ \\
\hline Kenalan & 30 & $30 \%$ \\
\hline Jumlah & 100 & 100 \\
\hline
\end{tabular}

Adapun Grafik dari data tersebut di atas dapat dilihat dari gambar berikut ini:

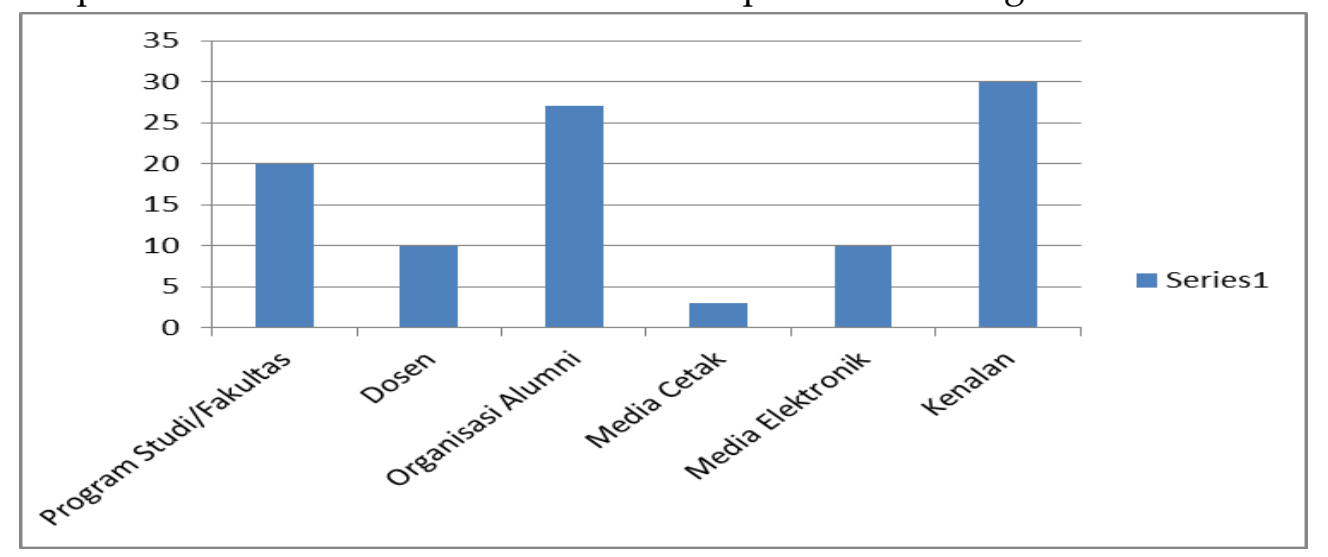

\section{e. Kesulitan untuk mendapat pekerjaan yang pertama}

Pada umumnya alumni merasa kesulitan mendapat pekerjaan pertama $80 \%$ ) disebabkan banyaknya pesaing yang sama - sama ingin mendapat pekerjaan.

\section{f. Kebutuhan akan kemampuan Bahasa Inggris.}

Karena umumnya alumni adalah menjdi guru Agama maka kebutuhan akan kemampuan Bahasa Inggris tidak begitu diperlukan.

\section{g. Kebutuhan pekerjaan akan Tehnologi Informasi.}

Dalam melaksanakan pekerjaannya kebutuhan akan tehnologi informasi dapat dilihat dari tabel berikut:

Tabel 6. Kebutuhan pekerjaan akan Tehnologi Informasi

\begin{tabular}{|l|l|l|}
\hline $\begin{array}{l}\text { Kebutuhan Tehnologi } \\
\text { Informasi }\end{array}$ & Banyaknya & Persentase \\
\hline Sangat membutuhkan & 80 & $80 \%$ \\
\hline Membutuhkan & 13 & $13 \%$ \\
\hline Cukup Membutuhkan & 5 & $5 \%$ \\
\hline Kurang Membutuhkan & 2 & $2 \%$ \\
\hline Tidak membutuhkan & - & - \\
\hline & 100 & $100 \%$ \\
\hline
\end{tabular}

Adapun Grafik dari data tersebut di atas dapat dilihat dari gambar berikut ini 


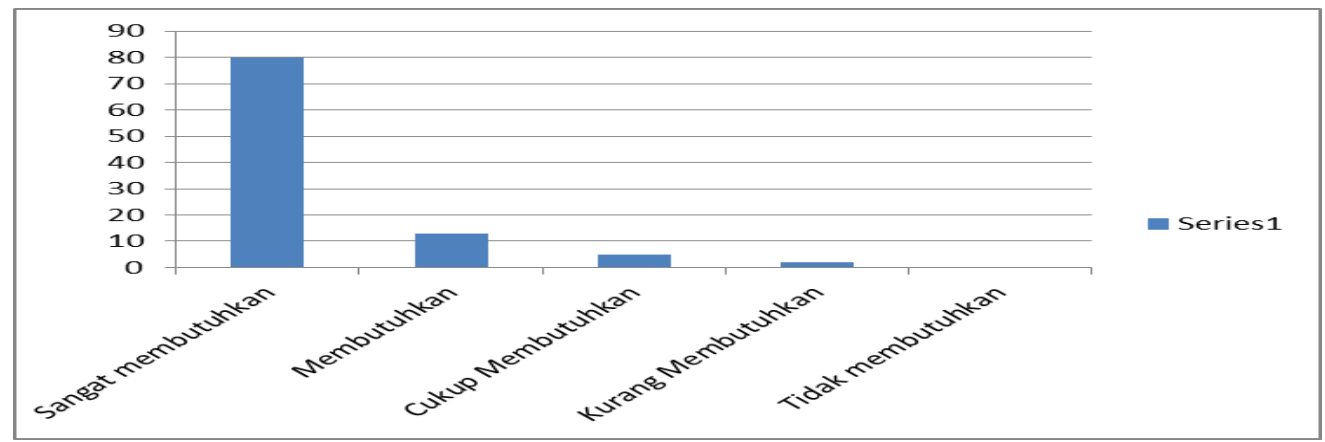

h. Pendapat alumni tentang Pengetahuan dan Ketrampilan yang relevan dengan kebutuhan dunia kerja yang perlu diberikan Prodi kepada Mahasiswa

1). Membekali mahasiswa dengan penguasaan tehnologi informasi yang baik karena pada saat ini kebutuhan akan ketrampilan tehnologi informasi sangat tinggi, semua sektor pekerjaan membutuhkan orang -orang yang terampil dalam IT, tidak lepas sekolah - sekolah tempat alumni mengabdi.

2). Hendaknya prodi dan fakultas membudayakan bahasa Inggris dalam interaksi sehari hari.

3). Penguasaan ketrampilan mengajar lebih ditingkatkan

4). Penguasaan Kompetensi mengajar lebih ditingkatkan

\section{i. Saran - Saran Alumni terhadap Perbaikan Proses Pembelajaran}

a. Sarana dan Prasarana harus lebih diperhatikan

b. Etika dan moral mahasiswa lebih ditingkatkan

c. Disipin mahasiswa dalam berpakaian harus lebih baik dengan membuat peraturan tersendiri karena akan menjadi guru

d. Dosen - dosen lebih meningkatkan kompetensinya

3. Penilaian pengguna terhadap kinerja lulusan Fakultas Tarbiyah dan Ilmu Keguruan IAIN Padangsidimpuan

Alumni Fakultas Tarbiyah dan Ilmu Keguruan tersebar diberbagai daerah. Adapun penilaian pengguna terhadap kinerja alumni adalah sebagaimana dalam tabel di bawah ini:

Tabel 7. Penilaian pengguna lulusan

\begin{tabular}{|c|c|c|c|c|c|}
\hline \multirow[b]{2}{*}{$\mathrm{NO}$} & \multirow[b]{2}{*}{ Jenis Kemampuan } & \multicolumn{4}{|c|}{ Tanggapan Pihak Pengguna } \\
\hline & & $\begin{array}{c}\text { Sangat } \\
\text { Baik }\end{array}$ & Baik & Cukup & Kurang \\
\hline 1 & Integritas (etika dan moral) & $85 \%$ & $15 \%$ & - & - \\
\hline 2 & $\begin{array}{l}\text { Keahlian berdasarkan bidang ilmu } \\
\text { (profesionalisme) }\end{array}$ & $90 \%$ & $9 \%$ & $1 \%$ & - \\
\hline 3 & Bahasa Inggris & $30 \%$ & $20 \%$ & $45 \%$ & $5 \%$ \\
\hline
\end{tabular}




\begin{tabular}{|l|l|l|l|l|l|}
\hline 4 & Penggunaan Teknologi Informasi & $80 \%$ & $15 \%$ & $3 \%$ & $2 \%$ \\
\hline 5 & Komunikasi & $87 \%$ & $10 \%$ & $3 \%$ & - \\
\hline 6 & Kerjasama tim & $80 \%$ & $15 \%$ & $5 \%$ & \\
\hline 7 & Pengembangan diri & $86 \%$ & $10 \%$ & $4 \%$ & \\
\hline
\end{tabular}

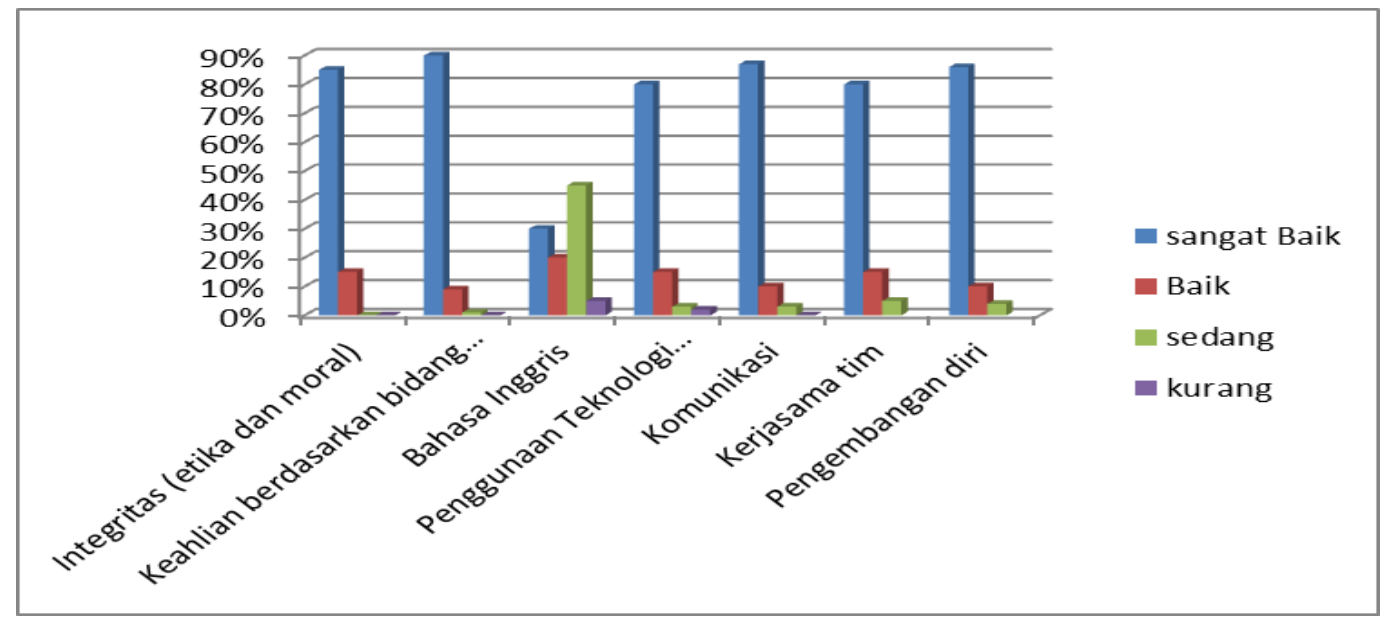

Dari garfik di atas dapat diketahui bahwa alumni Fakultas Tarbiyah dan Ilmu Keguruan mempunyai kinerja yang baik dalam pandangan pengguna mereka dilihat dari Integritas (etika dan moral), Keahlian berdasarkan bidang ilmu (profesionalisme), Penggunaan Teknologi Informasi, Komunikasi, kerjasama tim dan pengembangan diri, sedangkan dalam penggunaan Bahasa Inggris alumni masih kurang.

\section{PENUTUP}

Demikianlah uraian tentang tracer study yang dikaksanakan terhadap alumni Fakultas Tarbiyah dan Ilmu Keguruan Institut Agama Islam Negeri. Adapun hasil penelitiannya alumni memandang bahwa jadwal perkuliahan dilaksanakan dengan baik (85\%), dosen mengajar sesuai dengan jadwal perkuliahan $(87 \%)$, jumlah pertemuan di dalam proses perkuliahan memenuhi standar (95\%), penilaian yang dilaksanakan dosen memuaskan bagi mahasiswa (90\%), Dosen menunjukkan kualifaid dalam bidangnya (96\%) dan Dosen memberikan pelayanan diluar jadwal ( 80\%). waktu tunggu pertama untuk mendapatkan pekerjaan pertama sebahagian besar alumni antara $1-3$ bulan ( 50\%), 4-6 bulan 30\%, 7 - 9 bulan $15 \%$ dan 10-12 bulan $5 \%$. Pendapat alumni tentang Pengetahuan dan Ketrampilan yang relevan dengan kebutuhan dunia kerja yang perlu diberikan Prodi kepada Mahasiswa adalah membekali mahasiswa dengan penguasaan tehnologi informasi ., hendaknya prodi dan fakultas membudayakan bahasa Inggris dalam interaksi sehari - hari, penguasaan ketrampilan mengajar lebih ditingkatkan, dan penguasaan Kompetensi mengajar lebih ditingkatkan. Penilaian pengguna terhadap kinerja lulusan Fakultas Tarbiyah dan Ilmu Keguruan adalah baik. 


\section{DAFTAR PUSTAKA}

Badan Akreditasi Perguruan Tinggi , Buku III A Borang Akreditasi Program Studi, Jakarta: BAN PT, 2008.

Desy Anwar. Kamus Lengkap Bahasa Indonesia, Surabaya: Karya Abdi Tama, 2001

Institut Agama Islam Negeri Padangsidimpuan. Profil Program Studi Pendidikan Agama Islam Jurusan Tarbiyah , Padangsidimpuan:IAIN Padangsidimpuan, 2014

Kementerian Pendidikan dan Kebudayaan . Buku Panduan Sistem Pusat Karir, Jakarta: Dirjen Pendidikan Tinggi Direktorat Pembelajaran dan Kemahasiswaan, 2010.

Kementerian Pendidikan Nasional. Sistem Penjaminan Mutu Perguruan Tinggi , Jakarta: Direktorat Jenderal Pendidikan Tinggi, 2010.

Nana Syaodih Sukmadinata. Pengembangan kurikulum, teori dan praktek, Bandung: Remaja Rosda Karya, 2008.

Sekolah Tinggi Agama Islam Negeri Padangsidimpuan. Standar Dosen , Padangsidimpuan: STAIN Psp, 2013

Sekolah Tinggi Agama Islam Negeri Padangsidimpuan. Standar Mutu Mahasiswa, Padangsidimpuan: STAIN Psp, 2013

Sekolah Tinggi Agama Islam Negeri Padangsidimpuan., Manajemen Mutu Akademik, Padangsidimpuan: STAIN Psp, 2012.

Sudarwan Danim. Pengembangan Profesi Guru, Jakarta: Kencana Prenada Grup, 2012.

Surya Dharma. Manajemen Kinerja, Yogyakarta: Pustaka Pelajar, 2012 